\title{
14 Mining and the call for solidarity: the networks we have and the synodal network the Church is called to be
}

\author{
Vincent J. Miller
}

The details are painfully familiar: extractive zones scarred by ecological destruction, local populations suffering from poisoned water and air as well as social and cultural disruption, while local and national governments are corrupted by the cash the extracted commodities generate. Thousands of miles away, consumers enjoy the benefits of products made by these resources, rarely giving thought to the costs borne by others because they are largely unaware of them.

That lack of connection is not simply a moral blind spot, but a result of the powerful global market network that constructs and constrains relationships in which we are all viscerally enmeshed. Analyzing this as a network problem as opposed to a failure of moral will provides a more complex understanding of the problem and better guidance for contesting it. The church can also be considered a network with its own vision for how relationships should be structured. The relationships fostered by the church are currently weaker than global market relations. From a theological perspective, we are united to one another in Christ; but practically, Christians relate to fellow church members in distant lands primarily through the webs of the market. The mystical Body of Christ is too often bound together by the sinews of global capitalism. The church not only can, but, to remain true to its mission, must provide an alternate to the constrained relationships constructed by the global economy.

This essay will seek to chart ways in which the church can engage the mining practices that undergird industrial society. First, it will consider the power and history of the network of the global market in raw materials; then, it will review the standard means for influencing these markets and the mining projects that feed them; and it will conclude by proposing additional means for challenging the injustice of these projects that emerge when the church's capacity as a global network is taken seriously. As the Synod on the Pan-Amazonian Region demonstrated, the church can do more than exhort its members to exercise solidarity. It can function as a global network to facilitate deeper relationships of solidarity that challenge the shallow and often exploitative relationships fostered by contemporary capitalism.

DOI: $10.4324 / 9781003094272-14$ 


\section{The network we have}

Contemporary globalized capitalism comprises a network that reaches from the most developed cities to the least developed locations on earth. This is the most powerful and robust network that has ever existed, able to move valued resources from mines far from transportation hubs, energy sources, or skilled labor into global commodity chains that feed production in industrial centers. It is astoundingly resilient when compared to other essential networks such as education, health, or rule of law. Regardless of battles over territory, legality or illegality, sustainability or unsustainability, peace or war, strong, weak or failed state, minerals flow to manufacturers and products get made.

This economic network is heir to centuries of colonial extraction. Theologian Daniel Castillo (2019) offers a concise synthesis of critiques of the colonial legacies hidden within contemporary extractive economies. He describes a " 500 year project" in which the systems of colonial plunder became the basis for the capital accumulation that funded industrial society and Western modernity (142). Uruguyan Eduardo Galeano (1997; cited in Castillo 2019, 150), whom Pope Francis cites in Querida Amazonia, provides a contemporary witness to this expropriation: "Everything, from the discovery until our times, has always been transmuted into European-or later United States-capital, and as such has accumulated in distant centers of power." Castillo 2019 The Catholic Church confessed its complicity in this process during the Synod of Bishops Special Assembly for the PanAmazonian Region $(2019, \mathbb{\$ 1 5}$ ) in "The Amazon: New Paths for the Church and for an Integral Ecology" : "The proclamation of Christ often took place in collusion with the powers that exploited the resources and oppressed the local populations."

De las Casas' (1986, 2:57; cited and translated in Castillo 2019, 150-51) Historia de los Indios provides a colonial-era witness to this extractive regime:

Mountains are turned over from the bottom to top and top to bottom a thousand times; [the workers] dig, split rocks, move stones, and carry the earth on their backs to wash it in the rivers, and those who wash the gold stay in the water all the time with their waists bent so constantly it breaks their bodies.Castillo 2019

Add coltan, cassiterite, and a handful of other minerals; update the risks to include mercury and cyanide exposure; and de las Casas's description applies to countless extractive sites around the world today.

Castillo's analysis goes beyond tracing how the global economy continues the human injustices of colonialism. He argues that the legacies of colonialism lie within the very logic of extraction. The "technocratic paradigm" (the view that the world is a passive object open to human 
manipulation and exploitation) that Francis $(2015 \mathrm{~b}, \mathbb{\$ 1 0 6}$ ) decries in Laudato Si' has its roots in the colonial plunder which turned societies and cultures, forests and landscapes into sites of extraction and expropriation (Castillo 2019, 27-28, 146-61). The problems we face with contemporary extractive practices thus involve questions of injustice and violence both for those whose lands and livelihoods they impact, and for the ecosystems which they despoil, disrupt, and displace.

But these colonial legacies do not describe all the effects of the global mining market. Contemporary mining is often undertaken voluntarily, by a variety of actors, from artisanal miners and medium-scale lightly mechanized enterprises, to the mega-scale projects of major mining corporations. The balance of positives and negatives in these arrangements vary greatly. Artisanal mining has long been a part of the livelihoods of peoples located near easily accessible mineral sources. Medium-scale enterprises using cheap yet powerful earth-moving, washing, and refining processes can provide substantial wages for impoverished workers, but have very significant environmental impacts and are often tied to illegal actors. Major mining projects are often welcomed by national governments. Some producers have taken great pains to develop non-polluting processes and to negotiate with affected communities. Other large projects exploit weak regulatory regimes to extract maximum profit with little concern for costs borne by local residents and ecosystems. ${ }^{1}$ Economist and theologian Daniel Finn (2017) argues that justice-oriented activists should distinguish the operations of good actors from destructive ones and avoid blanket prophetic denunciation of the entire mining industry. ${ }^{2}$ There are responsible and destructive actors on all scales.

Both of these perspectives on the nature of mining are important. But here we are concerned with a different problem: how the contemporary structure of the global commodities market provides an outlet for raw materials regardless of the morality of their production. It is on this level that many systemic problems appear (see Arboleda 2020). The existence of legitimate global commodity markets has destabilizing effects because it also provides an outlet for illegal and unregulated extraction, undercutting efforts of good actors. This market is enormously adaptive, able to work through catastrophes and conflict. Villages get burned, populations are terrorized, activists are murdered, miners forced from territory, middlemen killed in turf wars, corporations gain and lose concessions, and still raw material supply flows unabated. As Rigobert Minani documents in his chapter on the Democratic Republic of the Congo, if there is a valuable mineral or resource that can be had, it will find its way into the global commodity market.

It is helpful to consider how this network's material structure provides the basis for certain ways of knowing, acting, and relating that construct and constrain our moral agency in ways we seldom realize. Here we will consider three interrelated aspects: market externalities, commodity distancing, and the price signal as a shallow form of relationship. 
One of the fundamental aspects of this global network is the problem of "externalities," costs associated with production that do not appear in the exchange price. These include pollution; destruction of watersheds, agricultural land, and local ecologies; exploitative and destructive labor practices; and physical and cultural violence against local populations. Externalities arise from the immorality of market actors who seek to maximize their profit by shifting costs to others and because any extractive undertaking has many consequences that go unremarked and might only manifest years after a project ends. The latter are inherently difficult to include in the price of exchange. Doing so requires stable and robust state and international regimes with the power to enact and enforce environmental and other regulations requiring producers to minimize pollution and exploitation-what Barrera calls "extra-market interventions" in his chapter in this book. Given the profound adaptability of markets, it is enormously difficult to enact such regulations on a global scale.

Thomas Princen (2002) has coined the term "commodity distancing" to describe how globally dispersed supply chains transform markets. As geographical distance increases, our knowledge about the context and consequences of products we consume decreases. At each point of exchange, only information relevant for the purchase-usually only quality and price-are passed along. This is exacerbated by cultural distance. End consumers have little or no knowledge of the predicaments of farmers, laborers, and communities at the other ends of supply chains, whether this is their political, cultural, economic, and legal situation or the ecological impact of production on the rest of their lives. Princen's comment about consuming Chilean grapes applies to any global commodity: "I have no way of knowing if my consumption is supporting or undermining that farmer, economically or ecologically. With no feedback, or uncertain feedback, I can only assume and, as with most of us, prefer to assume, that my purchases are supportive. I can only assume that all parties have entered the bargain voluntarily and that coercion or extreme dependency have not been the conditions of my enjoyment" (118). Princen's analysis reveals how this global network moves commodities and capital, but not all relevant information about them. This massive filtering of information facilitates the externalization of costs.

Finally, we must consider how economic structures have broader cultural impacts. This moves us out of the realm of economics and into consideration of cultural effects of market structures and how they elicit certain ways of being and relating. Market relations in which the primary form of communication is the price signal are extremely narrow forms of relationship. This is the source of the profound "efficiencies" that market structures enable. Focusing on one aspect of a relationship between parties-the price-enables the massively complex systems of production that characterize modern economies. Each party has a concrete measure by which to evaluate their interaction with others that can be managed through financial accounting. 
We need to consider how this powerful economic practice constructs and constrains our relationships. To stay in business, market actors must focus on the price signal. They may prefer one provider's business, labor, and ecological practices, or may prefer to purchase from a local firm, but if the cost is significantly higher, they will not be able to do so, lest their own products' prices become uncompetitive. The price signal disciplines and subordinates other value considerations. Thus, the global economy functions as a massive network of shallow relationships. It facilitates myriad relationships, but constructs them in an extremely narrow manner. Sometimes these are explicitly negotiated relationships between parties, but for the most part, these are implicit but real relationships within supply chains that contribute to the myriad products we consume.

\section{Means of influencing these networks}

These interrelated aspects of the global market system are not incidental side effects, but consequences of its central strengths. Thus, our attempts to counter these negative impacts require engaging the dynamics of the global economy itself. There are many methods of influencing these networks to limit their destructiveness and bring external costs into the market price. These include national legislation and international and sector agreements to minimize the actions of immoral actors and support moral ones. Two important policy foci involve transparency and the consent of those affected by extractive projects.

Transparency policies address problems caused by commodity distancing: the tendency of global commodity markets to obscure the origins of industrial materials. These seek to make supply chain accounting public by requiring firms to disclose their negotiations and payments regarding mining projects. One example is the Extractive Industry Transparency Initiative (EITI), a set of voluntary guidelines through which extractive companies and governments disclose all payments for audit and agree to work in partnership with civil society groups (see Lujala 2018; Bamat, Chassy, and Warne 2011, 15). Transparency can also be applied to manufacturers' supply chains. The most well-known manufacturing transparency regimes concern "conflict minerals" (tin, tantalum, tungsten, and gold) derived from mining in the Democratic Republic of the Congo. These include Section 1502 of the 2010 Dodd-Frank Wall Street Reform and Consumer Protection Act, which required publicly traded companies in the US to certify that their supply chains do not source minerals from conflict zones, $^{3}$ and the OECD Due Diligence Guidance for Responsible Supply Chains of Minerals from Conflict-Affected and High-Risk Areas, which provides similar regulations for European firms.

The 2008 United Nations Declaration on the Rights of Indigenous Peoples (2007) articulated the notion of "free prior informed consent" (FPIC) in all matters in which the rights, culture, and lands of indigenous 
people are affected by governments and businesses. Article 32.2 applied this to "any project affecting their lands or territories and other resources, particularly in connection with the development, utilization or exploitation of mineral, water, or other resources." This principle has been generalized to apply to any local community significantly impacted by mining, oil, gas, or any other major project that transforms land or has a significant lasting impact (Bamat, Chassy, and Warne 2011, 10). Communities near mining projects are often rural, poor, and politically and culturally marginalized. FPIC provides a standard to guide political and economic actors to address affected communities' concerns, seeking their consent rather than exploiting their marginality. FPIC has come under criticism as a framework easily manipulated by powerful mining firms against poor and marginalized communities and for being biased toward approval of extractive projects. In response, indigenous, religious, and NGO groups are advocating for "the right to say no"-to allow local communities to simply refuse such operations in their territories. ${ }^{4}$

This is important and often quite effective work. But it is essential to note how fragile these interventions are in contrast to the network itself. This is not simply because of the profound power of wealthy industry actors whose resources dwarf those of $\mathrm{NGO}$ and state actors who seek to regulate extractive industries. It has to do with a more fundamental asymmetry in the network itself. To mix a metaphor, market actors know the loopholes they need to operate, whereas those seeking to regulate a market must mind the entire dike of the global supply chain. Again, this problem is a direct consequence of the nature of market exchange. Market actors need only know the immediate local context of exchange: whether something can be sold at profit. While this can involve the strategic advantages of massive transnational corporations, often enough, it is equally a matter of very small-scale informal and black-market actors.

Given the breadth of global demand and the complexities and opacities of the many levels of manufacturing, local actors will almost always find a black-market outlet for destructively mined minerals. Think of the countless uses of gold-from electronics to jewelry. Big, publicly traded, transnational firms will work hard to certify that their supply chains are free of conflict minerals. But there are thousands of sites around the world where small-scale miners are destroying watersheds and ecologies with powerwashing, mercury, and cyanide, including sites where illicit armed actors are running the operations. Even if major producers have source monitoring regimes that exclude using them, there are countless smaller producers that will save material costs by sourcing from uncertified supplies, thus maintaining the revenue flow that sustains destructive mining and violence. 


\section{The church's current efforts}

The Catholic Church works in these processes in a number of ways. It accompanies affected communities, sharing in and documenting their suffering. This intimate knowledge forms the basis for policy advocacy. Advocacy on this level requires expert technical knowledge. Thus, ecclesial agency here tends to focus on elite participation: episcopal conferences and leaders and experts from their affiliated NGOs. Bishops call attention to destructive and exploitative practices and give voice to the plights of their victims. Episcopal conferences also provide a network which can monitor whether corporate and government action live up to promises made, as the Bishops of Cameroon and Chad did during construction of a pipeline in their region (US Congress 2007). Catholic Relief Services has worked to build capacity among local ecclesial and civil society groups so they can more effectively influence major extractive projects (Bamat, Chassy, and Warne 2011, 21). In El Salvador, the bishops worked with other Catholic and secular organizations in a successful campaign to pass national legislation to ban metal mining. Colombia is a more typical case. Multiple church actors are quite active in addressing mining issues at the local level. But these activities are not well coordinated and the bishops' conference has not developed a clear and consistent advocacy agenda at the national level. The chapter by Sandra Polanía-Reyes and Héctor Fabio Henao demonstrates how the Colombian Church is attempting to establish better coordination.

Because of their technical nature, such interventions are always susceptible to questions of religious legitimation. Do these appear to be part of the church's mission to people in the pews? They certainly are. But the abstract theological justifications for Catholic social doctrine often have little traction in the lived sacramental, liturgical, and communal experience of the Christian faithful. The technical nature of the regulation of extractive industries exacerbate this problem. For that reason, these sorts of actions often fail to gain strong support from much of the church and significant portions of the laity do not perform their expected role in this process of providing public pressure on governments to enforce environmental regulations, counter corruption, or ensure respect for the rights of threatened communities. This problem is why, as described by Polanía-Reyes and Henao, the bishops in Colombia have been trying to focus on better teaching and preaching of "eco-theology" that amplifies an understanding of the theology of creation in addition to a theology of salvation.

There is another problem inherent in the church's response, in addition to legitimation. It concerns the way the laity are addressed in such interventions, often as consumers. Greed and excessive consumption should, of course, be challenged. But invocations of greed can legitimate a false analysis that portrays market structures as morally neutral instruments that simply respond to the desires expressed in consumer demand. 
Not only does this prevent us from critiquing the way our networks are structured, it also tends to refocus the ecclesial response to working on the demand side. Many important theological critiques (e.g., cultivation of concern for creation or solidarity with the oppressed) are offered in ways that implicitly address the laity as consumers and are thus construed as a means of moderating individual desire, which can distract attention from systemic causes woven into the fabric of industrial civilization and the global commodity market.

Pope Francis has articulated two important concepts that address structural dimensions of these problems. They are, however, often incorrectly interpreted in a way that reduces them to an individual level: "the throwaway culture" and "the globalization of indifference." The notion of a "throwaway culture" is an insightful critique of contemporary consumercentered economies. Too often, however, this concept is reduced to an indictment of individual greed and consumer lifestyles. Consumer excess is a profound problem, but the crisis we face is not driven by the desires of the wealthy for shiny new gadgets. Yes, the tantalum and cobalt mined in conflict zones are used in the latest smartphones. But they are also in every electronic device-from hospital respirators to emissions-saving electric cars (Riofrancos 2019). As Daniel Finn $(2017,12)$ notes, extraction undergirds the whole of industrial society: "everything we touch throughout the day is either grown or extracted from the earth."

While Francis (2015b) does mention the need for a new "lifestyle," his extended discussion of the throwaway culture in Laudato $S i$ ' focuses on systemic issues of industrial production. He contrasts this with the circular flows of natural ecosystems, in which wastes from one part of the system feed and fertilize others. "Our industrial system ... has not developed the capacity to absorb and reuse waste and by-products. We have not yet managed to adopt a circular model of production capable of preserving resources for present and future generations. ...” (\$16). Francis's critique of the throwaway culture involves much more than consumer excess. It cuts to the heart of industrial civilization.

Francis discusses the "throwaway culture" in the context of the "globalization of indifference" in Laudato Si'. Francis first spoke about this at Lampedusa in 2013. "In this globalized world, we have fallen into globalized indifference. We have become used to the suffering of others: it doesn't affect me; it doesn't concern me; it's none of my business!" (Francis 2013b). He developed this notion more fully in Evangelii Gaudium, where he placed indifference in a more systemic context. Francis $(2013 a, \$ 53)$ called for expanding the Fifth Commandment- "Thou shalt not kill"- to the violence of economic systems: "we also have to say 'thou shalt not' to an economy of exclusion and inequality. Such an economy kills." He describes the globalization of indifference as a consequence of a view of the economy which assumes economic growth is adequate to bring about justice, trusting in the "sacralized workings of the prevailing economic system" (\$54). 
In Francis's fuller analysis, indifference is clearly characterized, not as an individual defect of will, but as a systemic disorder emerging from our economic context. My description of the three weaknesses of global market systems-externalities, distancing, and the attenuated form of relationships facilitated by the market's price mechanism - can be understood as an attempt to sketch the "architecture of indifference" in which the globalization of indifference emerges. It is not that "we should care, but don't." Rather, because of market externalities and commodity distancing "we don't know and can't know" the consequences connected to our consumption. Thus, it is impossible to care in any specific way (Miller 2014).

We have considered one of the structural factors that facilitates the destructiveness of mining: the way global capitalism connects the entire world in a network of shallow relationships, where the price signal is the primary form of communication that systematically obscures the broader conditions of production and destructive externalities. Laws, regulations, and industry standards that seek to counter these problems are always in danger of being outmaneuvered by market actors. We have seen that the church's involvement in these efforts suffers from two weaknesses. First, since it takes place on the level of experts and elites, it tends to be disconnected from the liturgical and sacramental life of the church. Second, in emphasizing the moral aspects of consumption, the church runs the risk of portraying these as demand-side problems arising from disordered desire, unwittingly obscuring the structural dimensions of the problem. In the final section we will explore how thinking in terms of networks will help re-envision the church's role in extractive markets and suggest new approaches for engagement.

\section{A fuller ecclesial response}

The church is materially, viscerally present on every level of this network. It is present in the communities who labor in mines and forests, who drink poisoned water, and who sometimes participate in the destruction of the land their children will inherit. It is present in the urban professionals supported by the proceeds of extractive industries and the wealthy parishes they attend. It is present in the consumers, rich and poor, who are fed, clothed, and housed by the products this system produces. The church is implicated at every level of these global chains, but those levels have little ecclesial relationship with one another. They are connected to one another, not by the church, but by the global commodity network. While theologically, we are united to one another in Christ, practically, we relate through global markets. The mystical Body of Christ is too often bound together by the sinews of global capitalism. The problem is thus not simply a matter of theology and morals, or of the formation of consciences. The problem is properly ecclesial, having to do with the nature and practice of the church. The church has something to say about the nature of human relationships. It must also consider the relationships in which it is entangled. 
Henri de Lubac's classic text Catholicism aimed to show, in the words of its French subtitle, the "social aspects of doctrine." De Lubac (1988 [1938], 15) argued that Catholicism is social "in the deepest sense of the word." It is social "in the heart of its mystery, in the essence of its dogma" to such an extent that the phrase "social Catholicism" should sound redundant. As the means and fruit of God's work of salvation, the church is not only essentially social, but the ultimate form of human sociality which all humankind are destined to share in Christ. De Lubac did not view secular forms of community dialectically. He accepted their goodness, noting the ancient Christian use of the city as an analogy for the church. But he held that the church was always called to a deeper intimacy than any earthly community could provide. "Among those who are received within this heavenly city there is a more intimate relationship than subsists among the members of a human society, for among them there is not only outward harmony, but true unity" (113-15, quote at 115).

De Lubac's theology found expression in the Second Vatican Council's understanding of the church and its mission. Lumen Gentium defined the church as a "sacrament or ... sign and instrument" of "a very closely knit union with God and of the unity of the whole human race." Thus, the church's very reason for existing, its religious mission, is to bring humankind into union. The council went on to note that this mission is intertwined with the secular dynamics that were bringing about human interconnection. In its words, this sacramental working of the church brings a world "joined more closely today by various social, technical and cultural ties" to a fuller unity in Christ (Second Vatican Council 1964, $\mathbb{\$} 1$ ).

The final document of the council, Gaudium et Spes, applied this understanding to the church's mission in the contemporary world. Gaudium et Spes spoke of the "socialization" being brought about by the growth of communications, and economic and political activity multiplying the "ties" among diverse men and women. This "growing interdependence" finds its fulfillment only on the "deeper level of interpersonal relationships." Such "communion between persons" fulfills the "laws of social life which the Creator has written into" human nature. Gaudium et Spes saw in the growth of global human interdependence the rise of a truly universal common good involving "rights and duties with respect to the whole human race" (Second Vatican Council 1965, \$6, 23, 26).

One of the key terms for this social unity is "solidarity." Gaudium et Spes explicitly connected solidarity with the social nature of salvation beginning in the Jewish covenant: "From the beginning of salvation history He has chosen men [and women] not just as individuals but as members of a certain community." This continues in the "the work of Jesus Christ" who taught his disciples to "treat one another as brothers" and sisters. The church, "His Body," is a community where "everyone, as members one of the other, would render mutual service according to the different gifts bestowed on each." This ecclesial communion is solidarity, which "must be 


\section{Vincent J. Miller}

constantly increased until that day on which it will be brought to perfection. Then, saved by grace, men will offer flawless glory to God as a family beloved of God and of Christ their Brother" (\$32).

The council understood that this communion has its ultimate realization as unity in Christ. My point here is not to stress that without Christ there can be no unity, but to note the very high stakes the church places on social communion. Thus, the shallow market relationships in which we are currently entangled are not secondary questions. They impinge upon the church's ability to pursue its mission to enact communion.

In Laudato Si, Pope Francis developed the church's social teaching by expanding solidarity to all creation. Francis $(2015$ b, $\$ 240)$ roots both solidarity among humans and the rest of creation in an ontology that reflects the triune, relational character of God.

The divine Persons are subsistent relations, and the world, created according to the divine model, is a web of relationships. Creatures tend towards God, and in turn it is proper to every living being to tend towards other things, so that throughout the universe we can find any number of constant and secretly interwoven relationships. This leads us not only to marvel at the manifold connections existing among creatures, but also to discover a key to our own fulfilment. The human person grows more, matures more and is sanctified more to the extent that he or she enters into relationships, going out from themselves to live in communion with God, with others and with all creatures. In this way, they make their own that trinitarian dynamism which God imprinted in them when they were created. Everything is interconnected, and this invites us to develop a spirituality of that global solidarity which flows from the mystery of the Trinity.

Francis $(2020, \$ 22)$ developed these themes further in Querida Amazonia:

Christ redeemed the whole person, and he wishes to restore in each of us the capacity to enter into relationship with others. The Gospel proposes the divine charity welling up in the heart of Christ and generating a pursuit of justice that is at once a hymn of fraternity and of solidarity, an impetus to the culture of encounter. The wisdom of the way of life of the original peoples-for all its limitations-encourages us to deepen this desire. In view of this, the bishops of Ecuador have appealed for "a new social and cultural system which privileges fraternal relations within a framework of acknowledgment and esteem for the different cultures and ecosystems, one capable of opposing every form of discrimination and oppression between human beings.

With these theological principles, we can judge the monstrous inadequacy of market relationships ruled by the price signal. But these insights do not 
simply judge an external reality. As we saw, the church is implicated in the structure of the global market. Its members relate to each other primarily through the market rather than through ecclesial connections. Thus, these theological principles are demands placed on the church itself to make such deep forms of relationship present in its own life.

Now that we appreciate the challenge that this global network poses to the church, we can begin to consider how it might respond. If the church is implicated in the destructiveness of global commodity flows and the shallowness of the human relations they construct, it can attempt to connect communities in a manner more consistent with its sacramental mission to unite humankind. If some members of the church are victims of conflicts fueled by mining, or fall ill from mining pollution, while others profit or consume products made from that mining, then the church can and should work to unite these members into deeper relationships of responsibility and reciprocity. Theologically, the church should aspire to be a network that encompasses and connects all its members, rather than merely be present in a network constituted by shallower logics. This task will always remain incomplete this side of the eschaton. But it is a work that, nevertheless, must be attempted.

There have been examples of success. Sharon Erickson Nepstad's account of the Central American Solidarity movement in the 1980s provides a hopeful and illuminative example. In a context riven by national boundaries and Cold War geopolitics, US and Central American Christians found ways to work together in solidarity to address the needs of those caught in the violent civil wars of that era. Nepstad recounts how North American missionaries and parish relationships served as an ecclesial connection across state borders. Returning missionaries served as bridge figures in their home communities, testifying convincingly to the innocence of victims of political violence at a time when the US government portrayed them as dangerous radicals (Nepstad 2004, 67-75). In these contexts, the oppressed appeared not as foreigners, but as brothers and sisters in Christ. Responding to their needs seemed, therefore, more than a matter of cosmopolitan ethics, but a question of Christian discipleship. It was a significant struggle for North American Christians to question their government and organize to change US foreign policy. The communications network provided by missionaries, intra-church partnerships, and church media provided knowledge and relationships that motivated and sustained advocacy by North American laity on behalf of their brothers and sisters in Central America.

The key lesson of this example is that the church provided alternative communication networks to government and secular media that enabled more direct communication between its members. Solidarity arose from this communication. It is important to note how this communication occurred in an ecclesial setting where it was easily connected to the liturgical and sacramental beliefs and practices of the church. 


\section{Vincent J. Miller}

How might something like this be enacted in the context of global commodity chains? It would involve cultivating properly ecclesial relationships to deepen the hidden, shallow relationships that currently connect us through commodity mining markets. The Catholic Church is one of the few organizations that has as broad a reach as the globalized commodity network. The church currently has several communication networks that are relevant. None, however, are used for this task.

The most central network of the Catholic Church is its episcopal hierarchy, which is in both theological communion and bureaucratic connection with the Vatican. While these networks are the most often invoked in discussions of catholicity, they tend to function primarily in spoke-like fashion, connecting each local church to the Church in Rome. They are less effective in connecting the local churches to one another. National and regional episcopal conferences allow for regional communication. New structures are needed to allow point-to-point global communication among local churches on a global scale. The planned continent-level discussions in the 2021-2023 Synod on Synodality have potential to address this problem.

The church also has the extensive networks of its Caritas affiliate organizations that connect the churches in the Global North with those in the Global South. These are impressive networks that can provide relief, development aid, and conflict resolution resources to communities in need (regardless of religious affiliation). Although they are not designed to establish communication between different parts of the church, some do fulfill this role. Catholic Relief Services, for example, facilitates global advocacy with its Catholics Confront Global Poverty partnership with other entities of the United States Conference of Catholic Bishops, and it organizes speaker programs to bring representatives from the field into the United States. This, however, takes place as a secondary supplement to its massive Overseas Operations which handles its disaster, development, and peacebuilding work. These are networks that provide resources and expertise to struggling communities. What if they were developed to allow for two-way communication that could allow needy communities to not only receive assistance, but to speak their experience and insights to the rest of the church?

Pope Francis (2015a) has sought to renew the Synod of Bishops in order to facilitate a "Church which listens." The 2019 Synod for the PanAmazonian Region provided a noteworthy advance in the church's work of advancing global solidarity focused on developing communication from the peripheries of the church and the global market. The preparation for the Synod involved hundreds of listening events in which more than 87,000 people participated (Brockhaus 2019). The working document for the Synod called for a "A dialogue in favour of life... at the service of the 'future of our planet,' of transforming narrow mentalities, of converting hardened hearts, and of sharing truths with all humanity" (Synod of Bishops Special Assembly for the Pan-Amazonian Region 2019, \$40). 
In his response to the synod, Francis spoke of this listening in terms evocative of the catholicity of the church. We listen not simply to hear other's struggles, but to learn what each culture has learned of God's wisdom in its landscape and ecology.

Human groupings, their lifestyles and their worldviews, are as varied as the land itself, since they have had to adapt themselves to geography and its possibilities.... In each land and its features, God manifests himself and reflects something of his inexhaustible beauty. Each distinct group, then, in a vital synthesis with its surroundings, develops its own form of wisdom. (Francis 2020, $\$ 32)^{5}$

The Synod on the Pan-Amazonian Region provides a glimpse of how ecclesial networks can provide a deeper connection between peoples than the global market system (Miller 2020). People around the world consume goods originating in the Amazon-from gold and iron to palm oil and soy-yet there are few opportunities to hear from those affected by their production in any depth. For three weeks in October of 2019, the church sought to "listen to the voice of the Amazon, stirred by the powerful breath of Holy Spirit in the cry of the wounded land and its inhabitants" (Synod of Bishops Special Assembly for the Pan-Amazonian Region $2019, \$ 3)$.

Evaluating mining projects requires an enormous depth of knowledge: the nature of the mining and refining processes being used, the ecology of the site, the economic, social, and cultural situation of those impacted by the project, the politics of the local concessions process, and the seriousness of negotiations with affected parties. While it is true, as Daniel Finn notes, that one can easily find blanket condemnations of all extractive projects that ignore the significant efforts some extractive corporations make to work in a just and sustainable manner, it is also true that for just about any project, even notoriously destructive ones, one can find legitimate-sounding documentary evidence of consultation processes, negotiations, and compensation. Only if one has access to detailed local knowledge can this evidence be judged adequately.

The Catholic Church has profound resources that could be mobilized on these issues. It is often present in the communities affected by mining projects and can help them voice their concerns. It can provide expert technical support and connect them with national, regional, and international networks. Rigobert Minani's discussion in this volume provides the compelling example of the work of the Episcopal Commission for Natural Resources in the Democratic Republic of the Congo. It has established diocesan "natural resource observatories" that monitor extractive projects for human rights violations. It works on the national level to advocate for just laws and policies for affected communities, and recently ran a program to help enfranchise artisanal miners so they can better navigate the legal 
systems for transparency monitoring and better participate in the marketplace. Working with civil society groups, it connects local concerns to advocacy on national, regional, and international levels.

Andrés McKinley's analysis in his chapter of the church's role in El Salvador's successful campaign to end metallic mining displays similar dynamics. The church, as McKinley describes, addressed the vulnerability and isolation of poor communities by providing the means to connect their resistance with advocacy campaigns on the national level. Church actors also facilitated a connection between global communities affected by the same mining firm by sponsoring the visit of a governor from a community in the Philippines to share their experience of the mining company's actions. In both cases, the church served as a network to connect communities that would otherwise be isolated so that they could better respond to the challenge posed by powerful mining interests. This connection between El Salvador and the Philippines was made through an international NGO that works on mining issues. There is nothing wrong with that. Note, however, the unrealized potential of the church's own network which could have been used to connect these communities in a more ecclesially powerful manner.

Guided by the principle of synodality, the church should further develop networks that enable people in extractive zones to speak with their brothers and sisters around the world; to share both their understanding and predicaments. If the contextual facts of every mining project are narratively dense, the church could provide connections that allow the richness of the stories to be shared: the impacts—for good and ill—on local populations; the landscapes and ecologies that are affected; and equally importantly, the local culture's understanding of the meaning of the landscapes they inhabit and the ecologies in which they participate. This could facilitate, in Leah Riofrancos's (2019, n.p.) words, "broadening our solidarities to encompass people we may never meet and places we may never visit but whose futures are bound up with our own."

If such communication were fostered by the church, it would make the religious relevance of these issues much more apparent. Rather than reading reports from experts (in our age of skepticism), believers could listen to the experience of fellow parishioners from across the globe. This would deepen their sense of connection and obligation. Equally important, by encountering the people at the other end of the supply chain, it would reveal to them how much is ordinarily hidden by our global supply chains. Knowing those affected by mining could foster a deeper inquisitiveness and distrust of products which do not disclose their supply chains (see Miller 2004, 184-86).

Such synodal listening to those at the extractive ends of global commodity chains could radically deepen the practice of FPIC, which currently functions largely as a contractual formality, inviting affected communities into a duediligence-like review of a proposed project. In its most sincere forms, it allows 
local communities to refuse a project. But it primarily imagines negotiations to minimize harms and find meaningful compensation. Francis's association of synodality with catholicity opens up the possibility for a deeper dialogue. Local communities could be given more than a "take it or leave it" offer for extractive development. A synodal communication network would allow them to dialogue with industrialized cultures about the nature of civilization. In the Amazon, there are indigenous civilizations that have lived in sustainable harmony with their ecologies for more than ten thousand years. We in industrialized societies, who have in a few short centuries mined our minerals, felled our forests, and now face ecological collapse on multiple fronts, have much to learn from such cultures. Rather than limiting communication to seeking their consent to our mining projects, the church could foster a deeper communion that would allow a two-way dialogue between parties already tied together via commodity flows. Listening would first confront us with the question, "Is our way of life worth the destruction of theirs?" Such a dialogue would also call industrialized society's way of life into question, helping to transform a civilization that is currently transgressing planetary boundaries on so many fronts.

This synodal ecclesial communications network does not currently exist. From a historical perspective, this is nothing new. The networks of Catholic communion are constantly changing and developing: from the Tridentine adoption of the printing press to foster liturgical and theological uniformity to the development of episcopal conferences to better organize church responses to the modern nation-state. The technology exists to enable the church to deepen its communications to match this theological need. If social media can sustain debate and friendship across space, they can certainly connect believers among distant local churches. If tens of millions daily watch livestreams of videogames and e-sports, these same technologies can certainly facilitate conversations between the peripheries and centers that can deepen relationships beyond those fostered by global capitalism.

\section{Conclusion}

This chapter has argued that many of the destructive impacts of mining are facilitated by the defects and cultural impacts of global commodities markets. The Catholic Church is itself a network, one that aims for a profound communion among all people. The fact that its members are currently more strongly formed by market relations than by its own logic of communion is a profound challenge. This challenge provides the possibility of new response, supplementing its current work of technical advocacy. By seeking to build ecclesial connections among its members, the church could form synodal relationships that deepen current market relationships into fuller responsibility and allow those affected to become full partners in a dialogue about our shared future in our common home. 


\section{Notes}

1 The chapter in this volume by Sandra Polanía-Reyes and Héctor Fabio Henao describes these different scales in the context of Colombia.

2 Also see Finn's more extended account of the morality of participating in global markets in his 2019 book Consumer Ethics in a Global Society: How Buying Here Causes Injustice There.

3 There is significant debate about the effectiveness of the Dodd-Frank provisions concerning conflict minerals. See Koch and Kinsbergen (2018) and Diemel and Hilhorst (2019).

4 For a discussion of the inadequacy of FPIC see Thea Riofrancos (2020). On the "Right to say no," see Justice, Peace, and Integrity of Creation Commission of the Union of International Superiors General-Union of Superiors General (2019), which proposed fostering the right of communities to say "no" to mining as a focal point of these religious orders' future work on the issue.

5 See also Francis's (2018) address at a meeting with indigenous people at Puerto Maldonado, Peru.

\section{References}

Arboleda, Martin. 2020. Planetary Mine: Territories of Extraction Under Late Capitalism. London: Verso.

Bamat, Tom, Aaron Chassy, and Rees Warne, eds. 2011. Extractives and Equity: An Introductory Overview and Case Studies from Peru, Angola and Nigeria. Baltimore, MD: Catholic Relief Services. https://www.crs.org/our-work-overseas/ research-publications/extractives-and-equity.

Brockhaus, Hannah. 2019. "The Amazon Synod, by the Numbers." Catholic News Service, October 11, 2019. https://www.catholicnewsagency.com/news/theamazon-synod-by-the-numbers-11205.

Castillo, Daniel P. 2019. An Ecological Theology of Liberation: Salvation and Political Ecology. Maryknoll, NY: Orbis Books.

de las Casas, Bartolomé. 1986. Historia de las Indias. Vol. 2. Edited by André SaintLu. Caracas: Biblioteca Ayacucho.

de Lubac, Henri. 1988 [1938]. Catholicism: Christ and the Common Destiny of Man. Ignatius Press: San Francisco.

Diemel, J.A., and D.J.M. Hilhorst. 2019. "Unintended Consequences or Ambivalent Policy Objectives? Conflict Minerals and Mining Reform in the Democratic Republic of Congo.” Development Policy Review 37, no. 4: 453-469. 10.1111/dpr.12372.

Finn, Daniel. 2017. "Recycling isn't enough: A Defense of Responsible Mining." Commonweal, May 2, 2017. https://www.commonwealmagazine.org/recyclingisn't-enough.

Finn, Daniel. 2019. Consumer Ethics in a Global Society: How Buying Here Causes Injustice There. Washington, DC: Georgetown University Press, 2019. 10.2307/ j.ctvswx $7 \mathrm{rz}$.

Francis. 2013a. Evangelii Gaudium. http://www.vatican.va/content/francesco/en/ apost_exhortations/documents/papa-francesco_esortazione-ap_20131124_evangelii-gaudium.html.

Francis. 2013b. Homily in “Arena” sports camp, Salina Quarter, Lampedusa. July 8, 2013. http://www.vatican.va/content/francesco/en/homilies/2013/documents/ papa-francesco_20130708_omelia-lampedusa.html. 
Francis. 2015a. "Address Commemorating the 50th Anniversary of the Institution of the Synod of Bishops." October, 17 2015. http://w2.vatican.va/content/ francesco/en/speeches/2015/october/documents/papa-francesco_20151017_50anniversario-sinodo.html.

Francis. 2015b. Laudato Si'. http://www.vatican.va/content/francesco/en/encyclicals/ documents/papa-francesco_20150524_enciclica-laudato-si.html.

Francis. 2018. "Address to Meeting with Indigenous People of Amazonia, Coliseo Regional Madre de Dios (Puerto Maldonado).” January 19, 2018. http:// www.vatican.va/content/francesco/en/speeches/2018/january/documents/papafrancesco_20180119_peru-puertomaldonado-popoliamazzonia.html.

Francis. 2020. Querida Amazonia. http://www.vatican.va/content/francesco/en/apost_ exhortations/documents/papa-francesco_esortazione-ap_20200202_querida-amazonia.html.

Galeano, Eduardo. 1997. Open Veins of Latin America: Five Centuries of Pillage of a Continent. New York: Monthly Review Press.

Justice, Peace, and Integrity of Creation Commission of the Union of International Superiors General-Union of Superiors General. 2019. "Statement from the Participants of the JPIC \& Mining Seminar.” September 27, 2019. https://www.jpicroma.org/ single-post/2019/08/27/JPIC-MINING-WORKSHOP-September-25-27.

Koch, Dirk-Jan, and Sara Kinsbergen. 2018. "Exaggerating Unintended Effects? Competing Narratives on the Impact of Conflict Minerals Regulation." Resources Policy 57: 255-263. 10.1016/j.resourpol.2018.03.011.

Lujala, Päivi. 2018. "An Analysis of the Extractive Industry Transparency Initiative Implementation Process.” World Development 107: 358-381. 10.1016/j.worlddev. 2018.02.030.

Miller, Vincent J. 2004. Consuming Religion: Christian Faith and Practice in a Consumer Culture. New York: Continuum.

Miller, Vincent J. 2014. "Slavery and Commodity Chains: Fighting the Globalization of Indifference.” America Magazine, January 3, 2014. https://www.americamagazine. org/issue/slavery-and-commodity-chains-fighting-globalization-indifference.

Miller, Vincent J. 2020. "We're All Tied to the Amazon Through Globalization. Can the Synod Help Us Listen to Its Cry?" America Magazine, February 19, 2020. https:/www.americamagazine.org/faith/2020/02/19/were-all-tied-amazonthrough-globalization-can-synod-help-us-listen-its-cry.

Nepstad, Sharon Erickson. 2004. Convictions of the Soul: Religion, Culture and Agency in the Central American Solidarity Movement. Oxford: Oxford University Press. 10.1093/0195169239.001.0001.

Princen, Thomas. 2002. "Distancing: Consumption and the Severing of Feedback." In Confronting Consumption, edited byThomas Princen, Michael Maniates, and Ken Conca, 103-132. Cambridge, MA: MIT Press. 10.7551/mitpress/2097.001.0001.

Riofrancos, Thea. 2019. "What Green Costs.” Logic 9. https://logicmag.io/nature/ what-green-costs.

Riofrancos, Thea. 2020. Resource Radicals: From Petro-Nationalism to PostExtractivism in Ecuador. Durham, NC: Duke University Press. 10.2307/j. ctv14t48kg.

Second Vatican Council. 1964. Lumen Gentium. http://www.vatican.va/archive/ hist_councils/ii_vatican_council/documents/vat-ii_const_19641121_lumen-gentium_en.html. 


\section{Vincent J. Miller}

Second Vatican Council. 1965. Gaudium et Spes. https://www.vatican.va/archive/ hist_councils/ii_vatican_council/documents/vat-ii_const_19651207_gaudium-etspes_en.html.

Synod of Bishops Special Assembly for the Pan-Amazonian Region. 2019. The Amazon: New Paths for the Church and for an Integral Ecology. http://www.vatican. va/roman_curia/synod/documents/rc_synod_doc_20191026_sinodo-amazzonia_ en.html.

UN General Assembly. 2007. UN Declaration on the Rights of Indigenous Peoples. A/RES/61/295. September 13, 2007. https://undocs.org/A/RES/61/295.

US Congress. 2007. House. Committee on Financial Services. Transparency of Extractive Industries, High Stakes for Resource-rich Countries, Citizens, and International Business. 110th Congress, First Session, October 25, 2007. Statement of Father Patrick Lafon, former Secretary General of the Catholic Bishops' Conference of Cameroon. https://www.govinfo.gov/content/pkg/CHRG-110hhrg 39913/html/CHRG-110hhrg39913.htm. 